\title{
SciDoC
}

Infer, Interpret \& Inspire Science

International Journal of Dentistry and Oral Science (IJDOS)

ISSN: 2377-8075

\section{Role of Dermatoglyphics as a Diagnostic Tool in Dentistry}

Research Article

\section{M.P. Santhoshkumar*}

Reader, Department of Oral and Maxillofacial Surgery, Saveetha Dental College and Hospital, Saveetha University, 162, Poonamallee High Road, Velappanchavadi, Chennai 600077, Tamil Nadu, India.

\section{Abstract}

\begin{abstract}
Dermatoglyphics isthe art and science of the study of surface markings and patterns of ridges on the skin of the fingers, palm, toes and soles. Dermatoglyphican alysis is proving to be as extremely useful tool for preliminary investigations into conditions with a suspected genetic basis. Over the past centuries, dermatoglyphics has evolved as a useful tool in the field of genetics, anthropology, biology, medicine and dentistry. Apart from their use for personal identification, the current state of medical dermatoglyphics is such that association between fingerprint patterns and various conditions such as diabetes mellitus, kidney diseases, hypertension, psychosis, breast cancer, alcohol embryopathy, epilepsy, congenital heart diseases and many others has been established. Recently, recognition of specific fingerprints among patients with periodontitis, dental caries, malocclusion, potentially malignant disorders, oral squamous cell carcinoma and congenital anomalies like cleft lip and palate has drawn attention of investigators to the field of dental dermatoglyphics. This article discusses about the history and embryogenesis, patterns of dermatoglyphics and the applications of dermatoglyphics in diagnosing several oral disorders. It also highlights the usefulness of dermatoglyphics as a diagnostic tool for many conditions in the field of dentistry.
\end{abstract}

Keywords: Dermatoglyphics; Finger Prints; Dentistry; Malocclusion; Impacted Teeth; Dental Caries; Genetics; Anthropology; Medicine.

\section{Introduction}

The term dermatoglyphics was coined by Cumins and Midloin 1926 and is derived from two Greek words: derma (skin) and glyphe(carve). It refers to the friction ridge formations which appear on the palms of the hands and soles of the feet. Dermatoglyphics isthe science and art of the study of surfacemarkings/ patterns of ridges on the skin of thefingers, palm, toes and soles [1]. These dermal ridges over the palms and soles of an individual are unique, universal, inimitable and classifiable. Finger, palm and sole impressions are said to be products of both environment and heredity. It is an established scientific fact that no two individuals, including monozygotic twins, have the same fingerprints and other details of dermal ridges. Thus, fingerprints are unique to each person and they are not altered during life time due to disease, age or any other reason.

Fingerprints are classified into three basic types: whorls, loops and arches. A whorl is distinguished by its concentric design, in which the majority of ridges make circuits around the core. The ridges of the loop instead of coursing in complete circuits, curve around only one extremity of the pattern and flow to the margin of digit. If the loop opens to the ulnar margin it is an ulnar loop, and if so to the radial margin it is a radial loop. In an arch, the ridges pass from one margin of the digit to the other with a distally bowed sweep [2]. Apart from their use in identification of individuals by forensic experts, the current state of medical dermatoglyphics is such that association between fingerprint patterns and various conditions such as diabetes mellitus, kidney diseases, hypertension, psychosis, breast cancer, alcohol embryopathy, epilepsy, congenital heart diseases and many others has been established. Recently, recognition of irregular fingerprints among patients with periodontitis, dental caries, malocclusion, potentially malignant disorders, oral squamous cell carcinoma and congenital anomalies like cleft lip and palate has drawn attention of investigators to the field of dental dermatoglyphics.

*Corresponding Author:

Dr. M.P. Santhoshkumar M.D.S,

Reader, Department of Oral and Maxillofacial Surgery, Saveetha Dental College and Hospital, Saveetha Institute of Medical and Technical Sciences (SIMATS), Saveetha University 162, Poonamallee High Road, Velappanchavadi, Chennai 600077, Tamil Nadu, India.

Tel: 9994892022

Email Id: santhoshsurgeon@gmail.com

Received: February 08, 2021

Accepted: March 22, 2021

Published: April 01, 2021

Citation: M.P. Santhoshkumar. Role of Dermatoglyphics as a Diagnostic Tool in Dentistry. Int J Dentistry Oral Sci. 2021;08(04):2146-2152. doi: http://dx.doi.org/10.19070/23778075-21000424

Copyright: M.P. Santhoshkumar ${ }^{\circ} 2021$. This is an open-access article distributed under the terms of the Creative Commons Attribution License, which permits unrestricted use, distribution and reproduction in any medium, provided the original author and source are credited. 
The development of dermal ridges starts from 12th-13th week of gestation and by around 20th week, well differentiated recognizable dermal ridges are formed. As genetic or chromosomal abnormalities might be reflected as alterations in dermal ridges, they can be used as an easily accessible tool in the study of genetically influenced diseases [3]. Dermatoglyphic investigation is convenient, cost effective and requires no hospitalization. It can help in predicting the phenotype of a possible future health condition. Human tooth development also starts as early as the 6th week of embryonic life. Since both dermal patterns and craniofacial constitution are strongly but not exclusively genetically governed structures, it may be hypothesized that hereditary and genetic factors causing changes in the lip, alveolus and palate may also cause peculiarities in fingerprint patterns. Now-a-daysimpacted tooth is one of the most commonly reported oral conditions and is widely prevalent. Genetic factors are one of the most commonly implicated putative aetiologic factors for this condition. According to the newer research, dental or skeletal malocclusion and the development of impacted teeth can be predicted utilizing the science of dermatoglyphics.

\section{History Of Dermatoglyphics}

Thousands of years before the birth of Christ, fingerprints were used on pottery to indicate the maker and brand of pottery and were also found in the tomb of Egyptian kings. The use of finger prints for personal identification is well known and evolved over many centurieswith its origin in the East. In China, the thumbprint of the Emperor was the ruler's mark on letters of state. Emperor Ts-in-She (B.C. $246-210$ ) was the first to use such seals in China. Nehemiah Grew was the first person to describe the pores, ridges and arrangements on the palm and fingers. Books published by Bidloo, Marcello Malphigigave a description of ridges on palms and fingers. During the 18th century, various accounts of epidermal ridges appeared in anatomical publications. In 1823, Joannes Evangelista Purkinje, suggested a classification system consisting of 9 basic types of finger print patterns [3].

William Herschelwas the firstto experiment with fingerprints in India.Francis Galton, published a book on "Fingerprints", classified the patterns and demonstrated the hereditarysignificance of fingerprints, and their use as a means of personal identification and ethnic differences.Edward Henry classified the fingerprint patterns and provided a basis for most ofthe other modern classification systems. HarrisHawthorne Wilder in the early 20thCentury, pioneered comprehensive studies onthe methodology, inheritance and racial variationof palmar and plantar papillary ridge patterns, aswell as finger prints [3].

Cummins and Midloin 1926 were the firstto coin the term 'Dermatoglyphics' [1]. CharlesMidlo M D et al publishedthe textbook "Fingerprints, Palms and soles", which is considered as a bible in thefield of Dermatoglyphics.Harold Cummins, Professor of Anatomy at Tulane University was the first person to show that palm and finger prints could be of use in clinical medicine.Cummins and Mildo et al, Penrose L S et al, Sarah Holt et al carried extensive research to find the association between dermatoglyphics and Down's syndrome with other congenitalmedical disorders.Galton Centerin 1965 [2] contributed to thedevelopment of dermatoglyphics and formulatedthe measurement to establish the position ofdisplaced axial tri radius in terms of atd angle, aswell as establishing the inheritance of its positionin the palm.

Schaumann and Alter's in their book 'Dermatoglyphics in Medical disorders'summarized the findings of dermatoglyphicpatterns in various disease conditions [4]. Engleret al predicted the risk of breast cancer from finger dermatoglyphics. Alexander Rodewaldet al, Stowens et al could diagnose many medical conditions like congenital, mental and systemic disorders with 90\% accuracy from the patterns of thehands [4]. Thus, currently the diagnosis of certain illnesses can be done accurately on the basis of only dermatoglyphic analysis.

\section{Embryogenesis Of Dermatoglyphics}

The knowledge concerning the mechanism of development of the epidermal ridge patterns is scarce, but a relationship to the fetal volar pads clearly exists because ridge patterns form at the sites of these pads. Fetal volar pads are mound-shaped elevations of mesenchymal tissue situated distal to the proximal end of the metacarpal bone of each finger, in each interdigital area, in the thenar and hypothenar areas of the palms and soles, and in the calcar area of the sole. The formation of these pads is first visible on the fingertips during the 6th to 7 th week of embryonic development. It has been established that the critical period of ridge formation begins i.e., about 3 months of age, when the volar pads are near or just beyond their peak development. The outer surface of the epidermis remains smooth whereas an undulation can be observed in the basal layer of the epidermis. This shallow epidermal proliferation is seen in the fourth month as distinct, clearly defined folds of the lower layer of the stratum germinativum growing downwards into the corium. The corium, in turn, forms papillae projecting upward into the epidermis. As growth continues, glandular folds divide at their tips and thus increase in number.The epidermal ridge patterns are completed only after the sixth prenatal month, when the glandular folds are fully formed and after the sweat gland secretion and keratinization have begun. At this time, the configurations on the skin surface begin to reflect the underlying patterns [5].

Several hypotheses have been formulated regarding the forces that are responsible for the development of specific ridge patterns. Schaumann and Alter described that dermatological markings mostly occur in the first four months of gestationand is being genetically determined and modified by environmental forces [4]. According to Bonneviean intimate connectionexists between shape, size, and degree of elevation of the volar pads and the specialconfigurations of their patterns. For example, small pads would result in a simple pattern (arch) whereas more prominent pads would tend to lead to the development of large and more complex systems of ridge configuration (loops and whorls). He also commented that fingerprint patterns depend upon the underlying arrangement ofperipheral nerves.

Cummins speculated that the dermal ridge configurations were the result of physical and topographic growth forces. It is believed that the tensions and pressures in the skin during early embryogenesis determine the directions of the epidermal ridges. Humphrey stated that digital andpalmar creases are secondary featuresrelated to flexion movements in thedeveloping hand between the seventh andfourteenth weeks of development. Gall and Associates stated, thatthe shape of volar pads determines fingertippat- 
terns, according to stricttopological principles. Penrosesuggested that ridges are aligned at right anglesto compression forces, and the abnormal configurations may be the result of alterations inthe fluid balance at an early embryonic stage. Therefore, ridge configuration is dependent on the shape of the volar pad at the time of initialprimary ridge formation, and the ridges follows lines of greatest convexity in the embryonic epidermis. A high volar pad wouldresult in formation of a whorl, while a low padwould result in an arch and an intermediate pad height offset to one side of the digit would resultin a loop formation [2].

Hirsch and Schweichel have postulated that the vessel-nerve pair induces the folds. Other factors that may influence epidermal ridge patterns include inadequate supply of oxygen to the tissues, deviations in the formation and distribution of sweat glands, disturbances in proliferation in the epithelial basal layer, and disturbances in keratinization of the epithelium. They also emphasized that theneuro-epithelium plays an important part in thedevelopment of the dermatoglyphic patterns. Babler reported that during the period of primary ridge formation, thatthe characteristic patterns are formed. At about 14 weeks, the primary ridge formation ceasesand secondary ridges begin to form. The dermal papillae are reportedto develop around the 24th week. Till then, the morphology of primaryand secondary ridges appears as a smooth ridgeof tissue and thereafter peg like structures, thedermal Papillae, characteristic of the definitivedermal ridges, are progressively formed. According to Babler there is arelationship between the volar pad shape and theepidermal ridge configuration with narrowvolar pads related to whorl patterns. It was also stated that significant correlations exist between the bonyskeleton of the hand and the epidermal ridgedimensions and time of ossification may be a keyfactor in ridge patterning [3].

The inheritance of dermal traits follows a polygenic model and the associations of such traits with oral malformations have been studied by Holt SB in 1968 [6]. The epidermal ridges of the fingers and palm and the facial structures originate from the same embryonic tissue, the ectoderm. The time of process of development and completion of primary lip and palate and that of dermal ridges are approximately the same, coinciding at 6th-13th week of intrauterine life. The dermal ridge configuration reaches its maximum at around 13 weeks of gestation and is completely established by the 24 weeks of gestation, and once formed, remain constant for lifetime, except in overall size. Facial development begins as early as the 4th week of gestation. The palate development begins in 6th week and is completed by the 12th week of gestation. Thus, the face and dermal ridges not only have the same origin but also develop concurrently.The genetic message contained in the genome is deciphered during this period and is also reflected in dermatoglyphic patterns. Thus, any environmental or genetic factors affecting the process of development of dental hard tissues might affect and also get recorded in the dermal ridges [4]. This forms the basis of comparison of malocclusion and impacted teeth with that of dermatoglyphics.

\section{Dermatoglyphic Patterns}

According to Galton, the ridge patterns on the distal phalanges of the fingertips into three Groups namely Arches, Loops and Whorls and the three basic dermatoglyphic landmarks found on the fingertip patterns are Tri-radii, Cores and Radiant $[1,7]$.
Arches (A) are the simplest pattern found on fingertips. The arch pattern is subdivided into two types: 1) Simple arch or plain arch (PA), composed of ridges, that cross the fingertip from one side to the other without recurving and 2) Tented arch (TA) composed of ridges that meet at a point so that their smooth sweep is interrupted. The point of confluence is called a tri-radius, because ridges usually radiate from this point in three different directions. In the tented arch, the tri-radius is located near the midline axis of the distal phalanx. Ridges passing over this radiant are abruptly elevated and form a tent like pattern and are designated as 'tented arch'.

Loops (L) are the most common pattern on the fingertip. A series of ridges enter the pattern area on one side of the digit, recurve abruptly, and leave the pattern area on the same side. If the ridge opens on the ulnar side, resulting loop is termed as ulnar loop (U,LU). If the ridge opens toward the radial margin, it is called a radial loop. $(\mathrm{R}, \mathrm{Lr})$. A loop has a single tri-radius or confluence point of ridges. The tri-radius is usually located laterally on the fingertip and always on the side where the loop is closed. Loops may vary considerably in shape and size and may be large or small, tailor short, vertically or horizontally oriented, Plain Loop (PL) OR Double Loop (DL). Occasionally, 'Transitional' loops can be found which resemble whorls or complex patterns.

Whorls (W) is any ridge configuration with two or more tri-radii with one tri-radius on radial and the other on the ulnar side of the pattern.The ridges in a Plain (Simple) whorl (PW) are commonly arranged as a succession of concentric rings or ellipses and aredescribed as concentric whorls (WC). Other configuration that spirals around the core in either a clockwise or a counterclockwise direction is termed as a Double whorl (DW) or a spiral whorl (WS). Sometimes, both circles and ellipses or circles and spirals are present in the same pattern. The size of the whorl can vary considerably, and is determined by means of a ridge count. A central pocket loop/whorl (CPL) (Wcp) is a pattern containing a loop within which a smaller whorl is located. Central pockets are classified as ulnar or radial according to the side on which the outer loop opens and are ordinarily grouped together as a CPL. Another type is composed of interlocking loops, which may form either a lateral pocket (WLP), twin or twinned loop (WT) pattern. Each has two tri-radii and the two types of whorls are morphologically similar. Complex patterns, which cannot be classified as one of the above patterns, are called Accidentals (A)/(WaCC) as there is a combination of two or more configurations such as a loop and a whorl, triple loops and other unusual formations. They are classified as Arch with Loop (AWL), or Arch with Whorl (AWW) [8].

\section{Methods Of Recording Dermatoglyphics}

Dermatoglyphic features offer at least two major advantages as an aid to the diagnosis of medical or Dentistry disorders. The epidermal ridge patterns on the hands and soles are fully developed at birth and thereafter remain unchanged throughout life. Scanning of the patterns can be recorded (prints) rapidly and inexpensively $[1,9]$.

A number of methods for recording dermatoglyphics exist. Methods vary in their requirements for equipment, time and ex- 
perience and in the quality of the prints obtained. Scanning by eyes alone often gives sufficient data but prints are necessary for quantitative analyses. The methods are ink method (Strong 1929, Purvis-Smith 1989), inkless method (Walker 1957) (Cummins and Midlo 1961), transparent adhesive tape method (Book 1948) and photographic method (Harrick 1962-1963). Special methods are hygro-photography (Sivadjian 1961, 1970), radiodermatography (Cummins and Midlo 1961, Pozhanski et a1 1969), plastic mold (Sutaman and Thomson 1952) and automatic pattern recognition (Trauring 1963). Braganca and Pick (1989) have developed a method where in the investigating region is blackened with graphite smeared on a piece of cardboard. The print is taken by Tesa film, adhered to a transparent film strip or photo-printing foil and the "negative" could be enlarged five or six times. Mull developed an apparatus which can record finger and palm prints without any inking and can automatically count ridge numbers between two singular points [9].

\section{Dermatoglyphics As A Diagnostic Tool In Den- tistry}

\section{Malocclusion}

Reddy et al. [10] reported that dermatoglyphics can be a predictor of malocclusion. A total of 96 study subjects were included in the study who were divided into four groups, with each group consisting of 24 individuals. Results indicated that craniofacial Class 2, division II pattern was associated with increased frequency of arches and ulnar loops and decreased frequency of whorls, whereas in Class 3, there was an increased frequency of arches and radial loops with decreased frequency of ulnar loops. Trehan et al. [11] also investigated the dermatoglyphic patterns in $60 \mathrm{mal}-$ occlusion patients. They observed that Class 1 and Class 3 were associated with increased frequency of whorls and both Class 1 and Class 2 division I were associated with increased frequency of radial loop and arches.

In the study by Tikare et al. [12] no association was observed between dermatoglyphic patterns and malocclusion among study subjects. It was however noted that whorl patterns were significantly associated with classes 1 and 3 malocclusions. According to Sahoo et al. [13] Ulnar loops were increased in vertical growth pattern,whereas whorls were increasedin horizontal growth pattern. There was absence of central pocket loops in vertical growth pattern.A study conducted by Divyashree et al. [14] concludedthat there is an increased frequency of who rls which were found both in right and left hands in skeletal class I pattern group. Increased frequency of ulnar loops was found in the right hand of skeletal class II pattern group.

A significant association between dermatoglyphic patterns and sagittal skeletal discrepancies was found in a research done by George et al [15]. They found an increased distribution of whorl pattern in the skeletal Class II with maxillary excess group and skeletal Class II with mandibular deficiency group, while there was an increased distribution of loop pattern in the skeletal Class III with mandibular excess group and skeletal Class III with maxillary deficiency group. The percentage of total ridge count was also higher in skeletal Class II with maxillary excess and skeletal Class II with mandibular deficiency and the ridge count could be considered for predicting skeletal pattern. They also stated that the left thumb impression fits the best model for predicting the skeletal pattern. An investigation done by Eslami et al. [16] concluded that although there were some slight differences in dermatoglyphic peculiarities of different skeletal malocclusions, most of thepalm and fingerprint characteristics did not show any significant differences.

Kharbanda et al. [17] evaluated and compared dermatoglyphicsof 25 males ofnorth India with true mandibular excess with ClassI occlusions. The authors inferred that in thesamplewith skeletal Class III base there was an increased incidence in arches and ulnar loops on all digits, except digit II.Reddy et al. [18] compared normal and malocclusion. The whorls of digit IV of both groups of both handshad statistically significant result whereas the ulnarloops of HGPhad statistical significance inrelation to digit IV. The striking feature wasthe absence ofcentralpocket loops in VGPs. Twinned loop of the right hand of HGP had a significant result.According to Ramagoni N K et al [19] there was no significant correlation between the finger print patterns, 'ATD' angle and the mesiodistal diameter of the deciduous second molar and the permanent first molar.Several studies have shown that dental/skeletal malocclusion can be predicted using finger/palmar dermatoglyphics.

\section{Bruxism}

Increased frequency of whorls and a decrease in frequency of ulnar loops were seen in patients with bruxism than the controls [20].

\section{Anomalies of Teeth}

Rodewald A et al [21] studied finger, palmar, and plantar prints of 8 males with X-linked hypohidrotic ectodermal dysplasia (HED), 8 carrier mothers, 7 sisters, and 1 carrier grandmother and compared them with data from 552 controls. The patients with HED and the carrier females had higher incidence of arches on the fingertips, of $t^{\prime \prime}$ triradii, of hypothenar patterns (especially ulnar loops), and of transversal direction of the main lines on the palms than the control individuals had. The affected males were also characterized by severe hypoplasia and/or dysplasia of the dermal ridges ("ridge flattening"); the carrier females also showed ridge flattening and hypoplasia.Kargül B et al [22] studied dermatoglyphic patterns in 3 hypohidrotic ectodermal dysplasia (HED) patients and compared them with 45 controls. This clinical evaluation (intraoral and radiological), genetic findings, dermatoglyphic patterns were analyzed. The HED patients had a higher incidence of ulnar loop patterns compared to the controls.

\section{Dental Caries}

Sharma A et al [23] and Ahmed et al. [24] found highly significant difference in loops between the subject (Caries) and control groups, and also observed significant difference between subject and control groups for microbial growth. Anitha $\mathrm{C}$ et al. [25] reported a definite variation in dermatoglyphics between the early childhood caries and caries-free group. Metin Atasu [26] studied dermatoglyphic configurations in caries-free students and the students with extensive caries and found there was significant difference in dermatoglyphic patterns in these two groups. Caries free students had more ulnar loops on the fingertips and the students with extensive caries had more whorls on the finger tips. 
According to the study done by Abhilash PR et al [27] on 1250 children, dental caries susceptibility of an individual increased with incidence of whorl pattern and it decreased with incidence of loop pattern.Vijender et al [28], Madan et al [29], and Sengupta et al [30], reported frequency of whorls more in caries group and the frequency of loops more in caries free group.Madhussudan et al. [31] and Agravat et al. [32] showed that prevalence of dental caries was highest among students with loop pattern compared to other finger patterns. According to Chinmaya BR et al [33], with an increase in the whorl pattern, there was an increase in dental caries. And with an increase in the loop pattern, there was a decrease in dental caries. Central pocket whorl and twinned loops were found to have an association with an increase in dental caries experience.

According to Reddy K V et al [34], the frequency of whorls was found to be more in caries group and frequency of loops more in caries-free group among the children with special health care needs. Thakkar VP et al. [35] reported that dental caries susceptibility of an individual increases with an increase in the incidence of whorl pattern. Padma et al. [36] in their study also found the frequency of whorls to be more in the caries group and the frequency of loops to be more in the caries-free group.Asif et al. [37] conducted a study to evaluate the dermatoglyphic pattern among deaf and mute children affected with caries and children without caries and concluded that the frequency of arches was found to be more in both caries and caries-free group. Fingerprints of caries-free females and females with caries showed more of arch followed by loops. In caries-free males, a common pattern was arch, and in males with caries, the pattern seen was arches followed by loops.

Bhat, et al. [38] conducted a study to evaluate dermatoglyphic peculiarities and caries experience of deaf and mute children. They observed that the frequency of whorls was more in caries group and the frequency of the loop was more in caries-free group. Madan, et al [39] in their study observed that Handprints of caries free children, especially females showed maximum ulnar loops. The caries group showed maximum occurrence of whorls which were more prevalent in females on the left-hand 3rd digit than in males where the whorls were found on the right-hand 3rd digit, and also low total ridge count, especially in males. In the study by Smitha S Shetty et al [40] it was observed that both male and female subjects had maximum of loop pattern and the male subjects showed no arch pattern. It was also noted that the subjects with increase in loop pattern showed high caries incidence. It was found that more than $50 \%$ of the individuals with arch pattern showed no dental caries.

\section{Cleft Lip and Palate}

Mathew L et al. [41] found increased frequency of ulnar and radial loops than the arches and whorls in cleft lip with or without cleft palate patients compared to controls. Interdigital patterns were less frequent in cleft lip and cleft palate patients. Balgir R S [42] studied dermatoglyphic characteristics of sixty-nine cases of cleft lip with or without cleft palate and twenty-eight isolated cleft palate cases. Wider 'atd' angle (more than 30 degrees) and dermatoglyphic asymmetry were noted in the patient groups. There was also a significant increase in the ulnar loop, arch patterns among the cleft palate patients when compared to the control groups.
Scott NM et al., [43] studied dermatoglyphic prints from individuals with non-syndromic CL/P $(n=460)$ and their unaffected relatives $(n=254)$ from the Philippines and China. The significant associations between particular pattern types and CL/P were not the same in both populations. An increased radial and ulnar loop were observed in Cleft lip and palate patients.

\section{Oral Potentially Malignant Disordersand OralCancer}

A study done by Samudrawar et al found increase in frequency of whorls, palmar patterns in I2-I3 area, total finger ridge count, total triradius count and decrease in atd angle with the absence $\mathrm{a}-\mathrm{b}$ ridge count in patients with oral leukoplakia and oral submucous fibrosis (OSMF) [44].

Veena HS et al. [45] found a decreased atd angle, increase in frequency of arches, increase patterns in Th/I1 area and increased pattern frequency in I4 area in OSMF patients as compared to normal gutkha chewers. The study conducted by GanvirSM et al [46] found that whorl type of fingerprint pattern was predominant in significantly higher number of individuals of oral squamous cell carcinoma (OSCC) and OSMF groups than in the control groups, wherein individuals of the control group showed loop as the predominant fingerprint pattern.Venkatesh et al., [47] performed a study on palmar dermatoglyphics in patients with OL and OSCC. Their results showed a significant increase in the frequency of arches in patients with OL and OSCC.

A study conducted by Gupta et al. [48] also showed promising results by observing an increased frequency of arches and ulnar loop patterns on fingertips with a decreased frequency of simple whorl patterns on fingertips and a decreased frequency of palmar accessory triradii on the right and left hands in oral squamous cell carcinoma patients. Significant findings in oral submucous fibrosis patients included an increase in the frequency of arches and ulnar loop pattern, decrease in the frequency of simple whorl patterns on fingertips, decrease in ATD angle on the right hand, and a decrease in the frequency of palmar accessory triradii on the right hand.

Shetty P et al., [49] in their study showed that Individuals with OSMF had higher number of whorl pattern than control group and individuals in the control group had higher number of arches pattern than the OSMF group.In oral cancers, dermatoglyphic patterns, grossly, have shown an increased frequency of arch pattern on the fingertips [50]. The study conducted by Kumar et al. [51] showed that there was a significant decrease of tented arches and ulnar and radial loops and an increase of simple whorls in OSF patients as against the controls.

\section{Periodontal Diseases}

Atasu M et al. [52] proved that dermatoglyphics could be used together with the other diagnostic methods such as clinical and radiologic investigations in the identification of the patients from distinct groups of periodontal diseases.According to Vaidya P et al [53], it was found that the periodontitis group showed more whorl patterns and the number of arches was less in periodontitis group in both the hands when compared to healthy controls.

In the study by Astekar S et al [54] among the finger ridge patterns, whorl pattern wasfound to be the common in the periodon- 
titis group whereas looppatternwas common in the control group. Mean total finger ridge count in the study group was significantly higher than the control group. Yilmaz et al. [55] performed a study among chronic periodontitis patients and periodontally healthy individuals. The results were similar to the study of Atasu et al. [52] and Babitha et al [56] which also showed increased frequencies of concentric whorls and transversal ulnar loops in chronic periodontitis patients.

\section{Impacted Teeth}

Abnormalities in the areas of palm and fingerprints are influenced by a combination of hereditary and environmental factors. The threshold theory as has been advanced by independent studies conducted by Carter and Matsunaga implies that only when the combined factors exceed a certain level, can these abnormalities be expected to appear. The etiological factors responsible for the manifestation of dermatoglyphic appearances and malocclusion might not cross this threshold for these conditions to manifest clinically.The pattern of impacted teeth has been found to be similar in members of the same family over several generations and hence, inheritance of this susceptibility is suspected. Genetic variations in the host factors may contribute to increased risks for impaction of teeth.According to Ramesh et al [57], Whorl type of fingerprints were observed more in impacted teeth patients whereas loop type of fingerprints was observed more in healthy patients.

\section{Down's Syndrome}

High frequency of simian crease, increase in ulnar loops on fingers and radial loop on digit 4 and 5 were detected in most of the studies done on down's syndrome patients [58-60].

\section{Turner's syndrome}

Existence of A-line in the thenar crease, Atd angle greater than 120 degrees, Ab ridge count greater than 105 degrees, increase in bilateral hypothenar area and loop patterns were observed in patients with turner's syndrome $[58,61]$.

\section{Conclusion}

Fingerprints are unique and unalterable and serves as an excellent tool for personal identification, screening population for several medical and dental conditions. Dermatoglyphics can serve as an easy, accessible, inexpensive, useful, reliable and noninvasive method of exploring the genetic associations of oral and craniofacial disorders and for timely intervention, however, it cannot be relied upon as the sole factor. This is due to the fact that numerous other factors such as ethnic and racial variations, congenital, environmental and other local factors can also influence the development of oral and craniofacial disorders. Extensive studies of ridge pattern have to be undertaken with several groups according to their racial and ethnic backgrounds.

\section{References}

[1]. Cummins C, Midlo C. Fingerprints, palms and soles- finger prints, palms and soles: An introduction to dermatoglyphics. Philadelphia: Blakinston Company. 1943; 11-15.

[2]. Galton F. Finger prints. London: Macmillan publishers. 1892;3-5.
[3]. Campbell ED. Fingerprints and palmer Dermatoglyphics. E-fingerprints. net. 1998.

[4]. Schaumann B, Alter M. "Dermatoglyphics in Medical disorders." (1976): $1-258$.

[5]. Mulvihill JJ, Smith DW. The genesis of dermatoglyphics. J Pediatr. 1969 Oct:75(4):579-89. PubmedPMID: 4309281.

[6]. Holt SB. The hypothenar radial arch, a genetically determined epidermal ridge configuration. Am J PhysAnthropol. 1975 Mar;42(2):211-4. PubmedPMID: 1119542.

[7]. Penrose LS, Ohara PT. The development of the epidermal ridges. J Med Genet. 1973 Sep;10(3):201-8. PubmedPMID: 4774533.

[8]. Wakita Y, Narahara K, Kimoto H. Multivariate analysis of dermatoglyphics of severe mental retardates: an application of the constellation graphical method for discriminant analysis. Acta Med Okayama. 1988 Jun;42(3):15968. PubmedPMID: 3400482.

[9]. Miller JR. Dermatoglyphics. J Invest Dermatol. 1973 Jun;60(6):435-42. PubmedPMID: 4351102.

[10]. Reddy S, Prabhakar AR, Reddy VV. A dermatoglyphic predictive and comparative study of Class I, Class II, div. 1, div.2 and Class III malocclusions. J Indian SocPedodPrev Dent. 1997 Mar;15(1):13-9. PubmedPMID: 9522763.

[11]. Trehan M, Kapoor DN, Tandon P, Sharma VP. Dermatoglyphic study of normal occlusion and malocclusion. J Indian Orthod Soc. 2000;33:11-6.

[12]. Tikare S, Rajesh G, Prasad KW, Thippeswamy V, Javali SB. Dermatoglyphics--a marker for malocclusion? Int Dent J. 2010 Aug;60(4):300-4. PubmedPMID: 20949762.

[13]. Sahoo N. A Comparative Study of Dermatoglyphics in Subjects with Hypodivergent and Hyperdivergent Growth Patterns. J IntSocPrev Community Dent. 2018 Nov-Dec;8(6):540-545. PubmedPMID: 30596046.

[14]. Divyashree SA, Sharmada BK. Tayeepriyanka. Dermatoglyphic patterns and their co-relation with skeletal malocclusions. J Dent Med Sci. 2016;15:1014.

[15]. George SM, Philip B, Madathody D, Mathew M, Paul J, Dlima JP. An Assessment of Correlation between Dermatoglyphic Patterns and Sagittal Skeletal Discrepancies. J ClinDiagn Res. 2017 Mar;11(3):ZC35-ZC40. PubmedPMID: 28511506.

[16]. Eslami N, Jahanbin A, Ezzati A, Banihashemi E, Kianifar H. Can Dermatoglyphics Be Used as a Marker for Predicting Future Malocclusions? Electron Physician. 2016 Feb 25;8(2):1927-32. PubmedPMID: 27054000.

[17]. Kharbanda OP, Sharma VP, Gupta DS. Dermatoglyphic evaluation of mandibular prognathism. J Indian Dent Assoc. 1982 May;54(5):179-86. PubmedPMID: 6956635.

[18]. Reddy BR, Sankar SG, E T R, Govulla S. A comparative study of dermatoglyphics in individuals with normal occlusions and malocclusions. J ClinDiagn Res. 2013 Dec;7(12):3060-5. PubmedPMID: 24551728.

[19]. Ramagoni NK, Kumar V, Adusumilli H, Reddy KP, Kumar NP. The Relation BetweenDermatoglyphics And Mesiodistal Width Of The Deciduous Second Molar And Permanent First Molar. J ClinDiagn Res. 2017 Aug;11(8):ZC60-ZC63. PubmedPMID: 28969275.

[20]. Polat MH, Azak A, Evlioglu G, Malkondu OK, Atasu M. The relation of bruxism and dermatoglyphics. J ClinPediatr Dent. 2000 Spring;24(3):191-4. PubmedPMID: 11314141.

[21]. Rodewald A, Zahn-Messow K. Dermatoglyphics findings in families with Xlinked hypohidrotic(or anhidrotic) ectodermal dysplasia(HED). ProgClinBiol Res. 1982;84:451-8. PubmedPMID: 6896579.

[22]. Kargül B, Alcan T, Kabalay U, Atasu M. Hypohidrotic ectodermal dysplasia: dental, clinical, genetic and dermatoglyphic findings of three cases. Journal of Clinical Pediatric Dentistry. 2002 Sep 1;26(1):5-12.

[23]. Sharma A, Somani R. Dermatoglyphic interpretation of dental caries and its correlation to salivary bacteria interactions: an in vivo study. J Indian SocPedodPrev Dent. 2009 Jan-Mar;27(1):17-21. PubmedPMID: 19414969.

[24]. Ahmed RH, Aref MI, Hassan RM, Mohammed NR. Dermatoglyphic study on patients with dental caries who wearing dental fillings and its correlation to apoptosis that induced by using dental fillings. Nat Sci. 2010;8:54-7.

[25]. Anitha C, Konde S, Raj NS, Kumar NC, Peethamber P. Dermatoglyphics: a genetic marker of early childhood caries. J Indian SocPedodPrev Dent. 2014 Jul-Sep;32(3):220-4. doi: 10.4103/0970-4388.135828. PubmedPMID: 25001441.

[26]. Atasu M. Dermatoglyphic findings in dental caries: a preliminary report. J ClinPediatr Dent. 1998 Winter;22(2):147-9. PubmedPMID: 9643190.

[27]. Abhilash PR, Divyashree R, Patil SG, Gupta M, Chandrasekar T, Karthikeyan R. Dermatoglyphics in patients with dental caries: a study on 1250 individuals. J Contemp Dent Pract. 2012 May 1;13(3):266-74. PubmedPMID: 22917994.

[28]. Vijender V, Tarannum T, Pathak A. Dermatoglyphics interpretation of dental caries: An in vivo study. Int J Dent Med Res. 2015;1(6):54-6.

[29]. Madan N, Rathnam A, Bajaj N. Palmistry: a tool for dental caries prediction! 
Indian J Dent Res. 2011 Mar-Apr;22(2):213-8. PubmedPMID: 21891888.

[30]. Sengupta AB, Bazmi BA, Sarkar S, Kar S, Ghosh C, Mubtasum H. A cross sectional study of dermatoglyphics and dental caries in Bengalee children. J Indian SocPedodPrev Dent. 2013 Oct-Dec;31(4):245-8. PubmedPMID: 24262398.

[31]. Madhussudan K, Patel HP, Umesh K, Chavan S, Patel R, Gadhavi N. Relationship between dermatoglyphics, chiloscopy and dental caries among dental students of Visnagar town, Gujrat. Int J Adv Res 2015;3:952-9.

[32]. Agravat D, Agarwal N, Patel P. Dermatoglyphics: A tool for dental caries prediction. J Adv Med Dent Sci Res 2014;2:66-9.

[33]. Chinmaya BR, Smitha BV, Tandon S, Khurana C. Dermatoglyphics: An indicator of dental caries in humans. J Indian Assoc Public Health Dent 2016;14:272-5.

[34]. Reddy KV, Kumar KN, Subramaniyan V, Togaru H, Kannaiah S, Reddy R. Dermatoglyphics: A new diagnostic tool indetection of dental caries in children with special health-care needs. Int J PedodRehabil 2018;3:1822.

[35]. Thakkar VP, Rao A, Rastogi P, Shenoy R, Rajesh G, Pai MB. Dermatoglyphics and dental caries: A cross sectional study among 12 year old school children in Mangalore, India. Indian Journal of Forensic Medicine and Pathology. 2014;7(1):19-25.

[36]. Bhat PK, Badiyani BK, Aruna CN, Chengappa S, Bhaskar NN. Dermatoglyphics-A new diagnostic tool in detection of dental caries among deaf and mute children. International Journal of Clinical Dental Science. 2011 Nov $1 ; 2(4)$.

[37]. Asif SM, Lahig AR, Babu DB. Dermatoglyphics: A tool in detection of dental caries. Journal of Advances in Medicine and Medical Research. 2016:1-5.

[38]. Bhat PK, Badiyani BK, Aruna CN. Dermatoglyphics-A new diagnostic tool in detection of dental caries in children. Indian Journal of Forensic Medicine \& Toxicology. $2012 \mathrm{Jul}$ 1;6(2):24.

[39]. Madan N, Rathnam A, Bajaj N. Palmistry: a tool for dental caries prediction! Indian J Dent Res. 2011 Mar-Apr;22(2):213-8. PubmedPMID: 21891888.

[40]. Shetty SS, Saran R, Swapna BV, Shetty S. Association of dermatoglyphics with dental caries and oral hygiene status. SRM Journal of Research in Dental Sciences. 2018 Jan 1;9(1):29.

[41]. Mathew L, Hegde AM, Rai K. Dermatoglyphic peculiarities in children with oral clefts. J Indian SocPedodPrev Dent. 2005 Oct-Dec;23(4):179-82. doi: 10.4103/0970-4388.19005. PubmedPMID: 16327138.

[42]. Balgir RS. Dermatoglyphics in cleft lip and cleft palate anomalies. Indian Pediatr. 1993 Mar;30(3):341-6. PubmedPMID: 8365784.

[43]. Scott NM, Weinberg SM, Neiswanger K, Brandon CA, Daack-Hirsch S, Murray JC, et al. Dermatoglyphic fingerprint heterogeneity among individuals with nonsyndromic cleft lip with or without cleft palate and their unaffected relatives in China and the Philippines. Hum Biol. 2005 Apr;77(2):257-66. PubmedPMID: 16201141.

[44]. Samudrawar R, Mazhar H, Wasekar R, Tamgadge P, Tiwari RV, Bhowmick S. Evaluation of Digital Palmar Dermatoglyphics in Oral Submucous Fibrosis and Leukoplakia: A Prospective Comparative Clinical Study. Journal of Maxillofacial and Oral Surgery. 2020 Jul 1:1-8.

[45]. Veena HS, Humbarwadi RS, Potturi BR. Cross-sectional study of palmar dermatoglyphics among gutkha chewers with and without oral submucous fibrosis. Karnataka, Bengaluru: Rajiv Gandhi University of Health Sciences.
2006 Mar.

[46]. Ganvir SM, Gajbhiye NY. Detection of genetic predisposition in oral squamous cell carcinoma (OSCC) and oral submucous fibrosis patients by qualitative analysis of finger and palm-print patterns: A dermatoglyphic study. Clinical Cancer Investigation Journal. 2014 Sep 1;3(5):377.

[47]. Venkatesh E, Bagewadi A, Keluskar V, Shetti A. Palmar dermatoglyphics in oral leukoplakia and oral squamous cell carcinoma patients. Journal of Indian Academy of Oral Medicine and Radiology. 2008 Jul 1;20(3):94.

[48]. Gupta A, Karjodkar FR. Role of dermatoglyphics as an indicator of precancerous and cancerous lesions of the oral cavity. ContempClin Dent. 2013 Oct;4(4):448-53. PubmedPMID: 24403787.

[49]. Shetty P, Shamala A, Murali R, Yalamalli M, Kumar AV. Dermatoglyphics as a genetic marker for oral submucous fibrosis: A cross-sectional study. Journal of Indian Association of Public Health Dentistry. 2016 Jan 1;14(1):41.

[50]. Fuller IC. Inherited predisposition to cancer? A dermatoglyphic study. $\mathrm{Br}$ J Cancer. 1973 Aug;28(2):186-9. doi: 10.1038/bjc.1973.135. PubmedPMID: 4730178.

[51]. Kumar S, Kandakurti S, Saxena VS, Sachdev AS, Gupta J. A dermatoglyphic study in oral submucous fibrosis patients. Journal of Indian Academy of Oral Medicine and Radiology. 2014 Jul 1;26(3):269.

[52]. Atasu M, Kuru B, Firatli E, Meriç H. Dermatoglyphic findings in periodontal diseases. International journal of anthropology. 2005 Jan 1;20(1-2):6375.

[53]. Vaidya P, Mahale S, Badade P, Warang A, Kale S, Kalekar L. Dermatoglyphics in periodontics: An assessment of the relationship between fingerprints and periodontal status-A cross-sectional observation study. Indian Journal of Dental Research. 2017 Nov 1;28(6):637.

[54]. Astekar S, Garg V, Astekar M, Agarwal A, Murari A. Genetic association in chronic periodontitis through dermatoglyphics: An unsolved link?. J Indian Acad Oral Med Radiol 2017;29:195-9.

[55]. Yilmaz S, Atasu M, Kuru B. A genetic and dermatoglyphic study on periodontitis. J Marmara Univ Dent Fac. 1993 Sep;1(4):297-306. PubmedPMID: 9582631.

[56]. Babitha GA, Yadav SC, Prakash S, Suresh K, Deotale S, Gaikwad S. Dermatoglyphics, $\mathrm{ABO}$ blood groups with Rh factor-An exploring link to periodontitis. Int J Curr Res. 2016;8:34224-8.

[57]. Ramesh DN, Thriveni R, Rachel BB, Manshi P, Byatnal A, Kempwade P. Comparative study to analyse the correlation between dermatoglyphics and impacted teeth. Journal of Indian Academy of Oral Medicine and Radiology. 2020 Apr 1;32(2):145.

[58]. Preus M, Fraser FC. Dermatoglyphics and syndromes. Am J Dis Child. 1972 Dec;124(6):933-43. PubmedPMID: 4265019.

[59]. Rajangam S, Janakiram S, Thomas IM. Dermatoglyphics in Down's syndrome. J Indian Med Assoc. 1995 Jan;93(1):10-3. PubmedPMID: 7759898.

[60]. Matsuyama N, Ito $Y$. The frequency of fingerprint type in parents of children with Trisomy 21 in Japan. J PhysiolAnthropol. 2006 Jan;25(1):15-21. PubmedPMID: 16617204.

[61]. Kobyliansky E, Bejerano M, Vainder M, Bat-Miriam Katznelson M. Relationship between genetic anomalies of different levels and deviations in dermatoglyphic traits. Part 2: Dermatoglyphic peculiarities of females with Turner's syndrome. AnthropolAnz. 1997 Dec;55(3-4):315-48. PubmedPMID: 9468759 . 